\title{
A Framework for Research on Corporate Accountability Reporting
}

\section{Citation}

Ramanna, Karthik. "A Framework for Research on Corporate Accountability Reporting."

Accounting Horizons 26, no. 2 (June 2013).

\section{Published Version}

http://aaajournals.org/doi/pdf/10.2308/acch-50412

\section{Permanent link}

http://nrs.harvard.edu/urn-3:HUL.InstRepos:10880584

\section{Terms of Use}

This article was downloaded from Harvard University's DASH repository, and is made available under the terms and conditions applicable to Open Access Policy Articles, as set forth at http:// nrs.harvard.edu/urn-3:HUL.InstRepos:dash.current.terms-of-use\#OAP

\section{Share Your Story}

The Harvard community has made this article openly available.

Please share how this access benefits you. Submit a story.

Accessibility 

H A R V A R D
B U S I N E S
S C H O O L

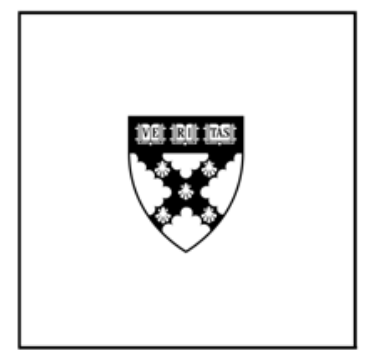

\title{
A framework for research on corporate accountability reporting
}

\author{
Karthik Ramanna
}

\section{Working Paper}

$12-021$

October 1, 2012 


\title{
A framework for research on corporate accountability reporting ${ }^{*}$
}

\author{
Karthik Ramanna \\ Harvard Business School \\ kramanna@hbs.edu
}

First draft: February 7, 2011

This draft: October 1, 2012

Forthcoming in Accounting Horizons

\begin{abstract}
This paper provides an accounting-based conceptual framing of the phenomenon of corporate accountability reporting. Such reporting is seen as arising from a delegator's (e.g., a citizenry) demand to hold a delegate (e.g., shareholders) to account. When effective, corporate accountability reporting can internalize certain externalities into firms' resource-allocation decisions, although doing so will not always serve shareholders' interests. I leverage the positive accounting literature's current understanding of properties of financial reports to develop three hypotheses on corporate accountability reporting. I argue that an accountability reporting system is likely to be more useful to a delegator if it: (1) mitigates information advantages across delegates and delegators; (2) reports both stocks and flows in the measures of account; and (3) has a mutually agreeable due process to match across periods the actions of delegates and the outcomes of those actions. I show how the successive incidence of these properties in observed corporate accountability reports can be used to determine whether and how those reports create or destroy value for shareholders and other constituencies.
\end{abstract}

\footnotetext{
* This paper has benefited from conversations with Paul Healy, Rebecca Henderson, Bob Kaplan, S.P. Kothari, Joshua Margolis, Mark Moore, Lynn Paine, Krishna Palepu, George Serafeim, Eugene Soltes, Sandra Sucher, Mike Toffel, and Ross Watts. I also thank the anonymous referees and the editor, Terry Shevlin. Matt Shaffer provided research assistance. I alone am responsible for any errors.
} 


\section{Introduction}

In August 2011, Harvard Business School (HBS), in collaboration with the Journal of Accounting \& Economics, announced a conference on corporate accountability reporting for January 2013. ${ }^{1}$ The announcement noted that "a growing number of forprofit corporations across the world have started voluntarily augmenting their annual financial reports with reports on 'corporate sustainability,' 'corporate social responsibility,' and 'corporate environmental performance,' among others.” The announcement highlighted a "need for a better understanding of the phenomenon" and called for papers that addressed that need. In the spirit of the HBS conference's call, this paper attempts to provide some conceptual framing on the phenomenon of corporate accountability reporting, particularly from positive accounting theory. In the paper, I leverage the positive accounting literature's current understanding of the role of financial reporting in a market economy and its understanding of the properties of financial reports to develop some basic hypotheses on corporate accountability reporting. Further refinement and tests of these hypotheses are likely to help us better understand some of the fundamental questions in corporate accountability reporting outlined in the HBS conference’s call for papers.

Corporate accountability reporting is defined to be broader than corporate accounting in that "accountability" reporting, unlike accounting, can be used to hold corporations to account for actions with externalities that are not entirely captured in revenues and expenses currently defined. The externalities can be "positive” (e.g., local community-building initiatives) or “negative” (e.g., environmental pollution, regulatory capture) relative to the state of the world where the corporation does not engage in the

\footnotetext{
${ }^{1}$ See http://www.hbs.edu/units/am/conferences/2013/corporate-accountability-reporting/
} 
action; and the internalization of externalities into firm decisions may or may not create value for extant shareholders. ${ }^{2}$ In this paper, I develop a framework to study corporate accountability reporting. ${ }^{3}$ In developing the framework, I explicitly approach corporate accountability as an observed phenomenon, and avoid speculating on whether companies ought to be held to account to customers, employees, and society, outside of shareholder maximization. I do not begin from these questions, because doing so is unlikely to provide a unifying framework, particularly for researchers employing positive methodologies. ${ }^{4}$ Rather, taking the position of an accounting academic observing some companies voluntarily reporting on environmental and social activities, and some activists demanding that more companies do so, ${ }^{5}$ I propose hypotheses that can help answer questions such as the following: Given our knowledge of the properties of corporate financial reporting systems, how can we evaluate the usefulness of extant corporate accountability reporting? In particular, when is such reporting likely to be useful to corporate constituents such as shareholders, bondholders, employees,

\footnotetext{
${ }^{2}$ Although economic theory has long acknowledged the distortions on prices from externalities, there is little consensus from the literature on how externalities can be internalized. For more on this topic, see the centennial issue of the American Economic Review, which included articles discussing the impact of externalities on unresolved problems of market failures and the commons (Ostrom, 2011; Stavins 2011).

${ }^{3}$ Corporate accountability is sometimes discussed under the rubric "corporate social responsibility." See Melé (2008) for a review of various approaches to studying corporate accountability. Also see Reinhardt, Stavins, and Vietor (2008) and Kitzmueller and Shimshack (2012) for recent assessments of the economics of corporate social responsibility. Beyond corporate accountability, there is also a cognitive-science literature on individual accountability: see, for example, Lerner and Tetlock (1999).

${ }^{4}$ There is a vast and vibrant literature in business ethics that explores corporate accountability from a moral-philosophy lens. For recent examples see, Hsieh (2009) and various chapters in Crane, McWilliams, Matten, Moon, and Siegel (2008), in particular, Scherer and Palazzo (2008).

${ }^{5}$ For descriptions of the evolution of corporate "non-financial" reporting, see, for example, Owen and O’Dwyer (2008) and Eccles, Serafeim, and Andrews (2011). Hopwood (2009) issues a call for research on accounting for the environment.
} 
customers, and society? When is such reporting likely to affect managerial decision making in ways that increase or decrease shareholder value? ${ }^{6}$

Consider, for example, the Deepwater Horizon oil spill of 2010 that resulted from an undersea explosion at a BP oil well in the Gulf of Mexico. For three months after the explosion, the leaking well spilled nearly 200 million gallons of crude oil into its surrounding environment. The spill caused significant ecological and economic damage, and also resulted in substantial tangible and intangible losses for BP. A bipartisan U.S. government commission created to study the incident concluded in November of 2010 that poor management decisions contributed to poor safety practices that, in turn, led to the explosion and its aftermath (e.g., BBC News, 2010). An internal probe by BP completed in September of 2010 also admitted partial blame (e.g., Bates, 2010). The management decisions at BP that contributed to the Deepwater Horizon incident are a potential illustration of misaligned management incentives. Could periodic reporting on the potential environmental impact of current management decisions on oilrig safety lead to decision-making that lowers the incidence of events such as the Deepwater Horizon explosion? If so, what are the properties of such a periodic reporting system? And, is the implementation of such a system likely to improve shareholder value?

The Deepwater Horizon incident can be used to motivate demand for improved accounting for externalities. Francis Bator (1958, p. 354), in his seminal article on the economics of externalities, discusses the "limitations on keeping book" as a potential cause of externalities, ${ }^{7}$ but then goes on to speculate that (p. 371) "a deeper analysis of

\footnotetext{
${ }^{6}$ The literature on assessing the impact of corporate accountability efforts on shareholder wealth spans several decades, but is largely inconclusive (e.g., Margolis and Walsh, 2001, 2003).

${ }^{7}$ In this sense, Bator's definition of "externalities" is broader than simply "technological externalities" that are due to physical laws of nature. Bator's externalities include those due to "institutional voids" (e.g.,
} 
this category [of externalities] may cause it to shrink substantially." Corporate accountability reporting can be viewed as an attempt to internalize certain externalities into management decision-making by “keeping book.”

The remainder of this introduction summarizes the structure of the paper and the analysis herein. In Section II, I offer a definition for corporate accountability that draws on the delegation or "agency" view of accounting. I argue that delegation necessitates accountability and that such accountability then involves reporting. The parallels to the relation between agency theory and financial reporting (explored in positive accounting theory) are germane: they suggest that accounting researchers have a comparative advantage in studying corporate accountability reporting. There are, of course, concerns with an agency-based view of accountability, particularly in viewing constituencies such as local communities as “delegators.” In Section II, I also show how these concerns can be conceptually distilled along two dimensions: the "legitimacy" of delegation and the “monitoring powers” of delegators. Classifying a given delegator-delegate relationship along these dimensions is an empirical exercise that is shaped by normative frameworks. In the remainder of my analysis, for expositional clarity, I assume legitimate delegation by delegators with relatively strong monitoring powers.

In Section III, I leverage the positive accounting literature’s current knowledge of some best-practice properties of corporate financial reporting to develop three basic hypotheses on corporate accountability reporting. ${ }^{8}$ Lessons from corporate financial reporting are likely to be useful to studying corporate accountability because such

Khanna and Palepu, 2010) or transactions-costs barriers (e.g., Williamson, 1985) and can be addressed through human ingenuity and entrepreneurship. Throughout the paper, I adopt this broader definition.

${ }^{8}$ For positive-accounting reviews, see for example, Watts and Zimmerman (1986), Ball (2001), Holthausen and Watts (2001), and Kothari, Ramanna, and Skinner (2010). 
properties have evolved and survived over long periods. In three successive hypotheses I argue that an accountability reporting system is likely to be more useful to a delegator if it: (1) mitigates information advantages across delegates and delegators; (2) reports both stocks and flows in the measures of account; and (3) has a mutually agreeable due process to match across periods the actions of delegates and the outcomes of those actions. The technologies specified in these hypotheses are common in financial reporting practice, but anecdotal evidence suggests they are not prevalent in accountability reporting. Further refinement and testing of these hypotheses can thus inform the development of more effective measures of corporate accountability.

Beyond assessing observed accountability reporting, there remain open conceptual questions for a literature in this area to tackle: in particular, whether and when corporate accountability reporting improves aggregate economic efficiency in a market society. In a complete market, prices have already impounded information relevant to scarce-resource allocation, so corporate accountability reporting is, at best, frivolous consumption. In Section IV, I provide a skeptical appraisal of corporate accountability reporting. I offer three explanations for observed corporate accountability reports. These are: (1) in Milton Friedman's words, “window dressing,” i.e., a superficial exercise that does not internalize externalities into firm decisions; (2) an attempt at internalizing negative externalities, as identified by one or more firm constituencies, into firm decisions; and (3) an attempt at internalizing positive externalities, as identified by one or more firm constituencies, into firm decisions. The first explanation takes a consumptionbased view of corporate accountability reporting resulting in no gains to aggregate economic efficiency. In the second and third explanations, net welfare effects can be 
positive. A systematic research agenda in corporate accountability reporting should eventually be able attribute observed instances of such reporting to one of the explanations above. I show how the hypotheses developed in Section III can be used to distinguish across the three explanations in observed corporate accountability reports.

I conclude in Section V by discussing the paper's implications for managers and others in practice. I also underscore the exploratory nature of the analysis herein: inductive learning through field research and rigorous testing through empirical analyses are necessary before the framework in this paper can properly be thought to constitute a theory of corporate accountability reporting.

\section{Defining corporate accountability: A delegation-based view}

I begin by adopting a definition of accountability. I draw from Staubus (2003), who defines accountability as "the obligation of a person entrusted with a duty to others to explain his/her performance of that duty." Staubus' definition, being based on the dictionary entry to "accountable" in Webster's Seventh New Collegiate Dictionary, is relatively straightforward and uncontroversial. This is a helpful place to start when dealing with an issue as complex and contentious as "corporate accountability." Based on the definition above, I propose that corporate accountability is the obligation of a corporation entrusted with a duty to others to explain its performance of that duty.

In the definition above, "the entrusting of a duty" necessitates accountability. In this phrase, I interpret the idea of a delegated relationship. That is, without Party A delegating a responsibility ("entrusting a duty") to Party B, the latter is not accountable to the former. The delegation-based view of accountability is in contrast to other possible 
avenues to studying accountability, including those based on moral philosophy (e.g., a Kantian rights and duties approach), on an intrinsic desire to be accountable, and on executory relationships (where there is no delegation from Party A to Party B; instead both parties are equals who interact on an as-needed basis). ${ }^{9}$

Webster's/Staubus' definition of accountability also requires the delegated party “to explain his/her performance.” In the framework, I interpret “explain” to involve reporting. Thus, in this view, corporate accountability is accomplished (at least in part) through the production of corporate accountability reports. Beyond "reporting," other potential institutions likely matter-in particular, the threat of punishment or, more specifically, legal liability, which can achieve accountability, for example, by enforcing the "fiduciary principle." ${ }^{10}$ Under a reporting-based view, the threat of punishment can play a facilitating role in accountability (e.g., by ensuring that such reporting is truthful), but such a role is indirect. In adopting “reporting” as a primary institution of corporate accountability, I include both formal reports that may be prepared and assured in accordance with generally accepted standards (such as the Global Reporting Initiative's Sustainability Reporting Guidelines; GRI, 2001-2011), as well as more informal reports such as corporate press releases and presentations on environmental and social sustainability, ${ }^{11}$ which the accounting literature studies in the context of financials under the mantle of "disclosure.”

\footnotetext{
${ }^{9}$ See footnote 4 for citations to some studies taking a moral-philosophy view of corporate accountability. Tetlock (1983, p. 74) defines accountability as "the need to justify one's views to others" and initiates a literature taking an intrinsic-desire approach to accountability. Parts of the model of corporate accountability in Hill and Jones (1992) are implicitly based on executory relationships (i.e., "the existence of an exchange relationship,” p.133).

${ }^{10}$ See, for example, Cooter and Freedman (1991).

${ }^{11}$ See http://www.hbs.edu/units/am/conferences/2013/corporate-accountability-reporting/databases.html for a list of databases of corporate accountability reports.
} 
The definition of accountability that I have adopted above yields two axioms that can serve as a basis for a framework for corporate accountability reporting: (1) that delegation necessitates accountability; and (2) that accountability involves reporting. As axioms to a framework, these statements are not assumed to be always true in practice; rather, the statements serve as a starting point for developing the hypotheses in Section III. A systematic body of evidence that is inconsistent with the hypotheses could invalidate the axioms.

\section{A critical analysis of the delegation-based view of accountability}

The framing of accountability as arising from delegation raises important conceptual issues about the nature of such delegation. In the case of delegation between shareholders and bondholders or between shareholders and managers, the nature of the delegated relationship is well specified, usually in formal legal contracts, and consequently, well understood. In contrast, in framing the relationship between shareholders (or their agents, managers) and constituencies such as employees, customers, and local communities as "delegated," there is a concern that such a delegation may not exist at all. ${ }^{12}$ The distinction between "explicit” delegation (such as the delegation of corporate management responsibilities by shareholders to a chief executive officer) and "implicit" delegation (such as, perhaps, the delegation of environmental stewardship by a citizenry to an oil company) can be useful in reconciling

\footnotetext{
${ }^{12}$ The framing of an employee's relationship with shareholders as "delegator" and "delegate," respectively, is unusual in the general sense that employees are usually considered the agents. However, in the context of discussing an employer's obligation to provide for the basic welfare (e.g., safety) of employees (particularly given information asymmetry and specific-asset investments by the latter), the framing can be usefully applied to study accountability reporting (e.g., Hill and Jones, 1992, p. 134).
} 
this concern. ${ }^{13}$ Explicit delegation is usually inferred from formal contracts and reflects situations where outcomes expected of delegates are measurable. ${ }^{14}$ The substance of implicit delegation surfaces in the literature on incomplete contracting (e.g., Hart, 1995; Tirole, 1999) and, more recently, in the literature on "relational contracts," (e.g., Gibbons, 2010), where transaction costs (including the costs of "keeping book”) preclude complete contracting. Corporate accountability reporting from shareholders (or managers) to constituencies such as employees, customers, and local communities, if effective, can be seen as an informational conduit that sustains and improves the functioning of "incomplete" and "relational" contracts between these groups. Relational contracts have also been shown to affect financial reporting numbers in potentially distortionary ways (Bowen, DuCharme, and Shores, 1995) and value-additive ways (Hayes and Schaefer, 2000); so future empirical work can examine how improved corporate accountability reporting affects the influence of relational contracts on financial reporting choice.

But the concern that not all relationships between shareholders (or managers) and other firm constituencies are "delegated” can reflect other factors as well. In particular: (1) the ownership claims of constituencies such as employees, customers, and local communities on resources that are under the control of shareholders are not well established; (2) the monitoring powers of such constituencies over shareholders (even if their ownership claims can be established) are poorly defined. The first issue (ownership claims) is related to whether the delegation is "legitimate" (has a basis in law or equity)

\footnotetext{
${ }^{13}$ On implicit delegation from society to corporations, see Scott (2009, p. 49) who argues that states charter firms in part so that the latter may contribute towards "societies' general socioeconomic well-being."

${ }^{14}$ See the vast contracting literature in accounting and economics; some recent reviews include: Lambert (2001), Bushman and Smith (2001), and Armstrong, Guay, and Weber (2010).
} 
or illegitimate (extortionary). The second issue (monitoring powers) is related to the problem of "weak" principals: a delegator's monitoring powers are likely to be a function of relatively sticky geographical or industrial political economies. ${ }^{15}$

The ownership claims and monitoring powers of a constituency can be organized as two dimensions of a matrix as in Figure A. The dimensions are likely to be continuous in scale, but for exposition, I divide each dimension into "strong" and "weak" regions. Thus, a constituency may have a "strong” or "weak" ownership claim on resources under shareholders' control and may concurrently enjoy “strong” or "weak” monitoring powers over shareholders. This classification traces out a 2x2 matrix, which can help determine the appropriateness of the delegation-based model for corporate accountability reporting.

Bondholders, it can be argued, have both relatively strong ownership claims on resources under shareholders' control and relatively strong monitoring powers (although the strength of the claims and monitoring powers vary considerably across countries; e.g., La Porta, Lopez-de-Silanes, Shleifer, and Vishny, 2000). Thus, in Figure A, bondholders (particularly in developed common-law countries) are likely to be located in the upper right quadrant (Quadrant I). Rank-and-file employees, on some issues also have strong ownership claims on resources under shareholders' control (e.g., their claim on workplace safety), but whether they enjoy strong monitoring powers over shareholders is likely to vary based on the presence of complementary institutions such as labor unions and labor laws. In a country with relatively weak labor unions (e.g., China), we can

\footnotetext{
${ }^{15}$ The problem of "weak" principals is discussed in the management sociology literature under the rubric of "power." Mitchell, Agle, and Wood (1997, p. 865) define "power" from Weber (1947) as "the probability that one actor within a social relationship would be in a position to carry out his own will despite resistance." Hill and Jones (1992) attribute "power differentials" between agents and principals (where principals are disempowered) to the problems of: "diffuse" principals (and coordination costs induced thereof); and "specific-asset investments" by principals.
} 
expect rank-and-file employees to be in the lower right quadrant (Quadrant II); while in a country with relatively strong labor unions (e.g., Germany), we can expect them to be in the upper right quadrant (Quadrant I). Government officials can usually be expected to enjoy relatively strong monitoring powers over shareholders (except in failed states such as Somalia), but can variously be argued to have strong or weak ownership claims on resources under shareholders' control. In cases where the ownership claims have a basis in law (e.g., as with legal tax collection), we can expect government officials to be in the upper right quadrant (Quadrant I); in cases where the ownership claims are extortionary (e.g., as with corrupt public officials), we can expect government officials to be in the upper left quadrant (Quadrant IV).

The quadrant location of a constituency is likely to affect the properties of corporate reporting aimed at providing accountability to that constituency, including the quality of that reporting. Such cross-sectional variation can generate substantial future research opportunities in corporate accountability reporting. In the following subsection, I briefly discuss some of these opportunities, particularly as they relate to current accounting research. But, for expositional simplicity in the remainder of the paper, in employing the delegation-based view of accountability between shareholders (or managers) and other constituencies, I assume strong ownership claims and monitoring powers on part of the latter.

Research opportunities from the delegation-based view of accountability

There are several research opportunities that emerge from taking a delegationbased view of accountability. First, it is agency theoretic; i.e., accountability is 
characterized as an agency problem. ${ }^{16}$ This is useful in that the study of certain agency relationships of corporations is well developed, thus potentially lending to the study of corporate accountability a vast body of theory and evidence. For example, an extensive literature in accounting has explored the influence of agency conflicts between shareholders and managers and between shareholders and bondholders on the properties of financial reporting (see Armstrong et al., 2010, for a recent review). Many other such agency relationships can be thought to exist between various parties to the firm: e.g., between shareholders and customers, between shareholders and employees, and between shareholders and local communities (although, as noted earlier, the validity of characterizing such relationships as "agency" can vary along ownership claims and monitoring powers). The various forms of reporting on corporate accountability, such as reporting on environmental practices, labor practices, and corporate corruption, can be seen as arising to address such agency relationships. Conclusions from the extant literature on the influence of the agency relationships between managers, shareholders, and bondholders on the properties of financial reporting are thus germane. Such conclusions can be applied in developing hypotheses on how other agency relationships of the firm can influence corporate accountability reporting.

\footnotetext{
${ }^{16}$ Jensen and Meckling (1976, p. 309) recognize the potential application of agency theory to corporate accountability noting how the problem of agency "exists in all organizations and in all cooperative efforts at every level of management in firms, in universities, in mutual companies, in cooperatives, in governmental authorities and bureaus, in unions...” See also, Arrow (1985). Hill and Jones (1992) combine agency theory with stakeholder theory to provide a theoretical foundation for corporate accountability. This paper differs from Hill and Jones in a number of ways: (1) Hill and Jones are not explicitly concerned with corporate accountability reporting and thus do not develop implications of their study for such reporting; (2) the Hill and Jones model presupposes market inefficiencies; this paper assumes externalities, but is otherwise agnostic on the informational efficiency of markets; (3) in the Hill and Jones model, corporate managers, not shareholders, are always the "agent;" in this paper, the "delegate" can be either shareholders or managers, since the precise identification of a delegate will vary with context.
} 
Second, by characterizing accountability as arising from delegation, the demand for accountability is characterized as a first-order problem, emerging from a behavioral model of human nature and independent of institutions and the time period. This is because the basic characterization of the principal-agent problem is independent of specifics on the principal and agent (e.g., their age, education, employment background, physical location, personal wealth, etc.); e.g., Ross (1973). Meeting the accountability demand through reporting, however, is likely to depend on contextual factors, in particular, complementary institutions that support such reporting. A well-developed literature in accounting has explored how cross-sectional and time-series variations in institutions such as analysts, auditing, courts, and regulations affect the properties of financial reporting (see Beyer, Cohen, Lys, and Walther, 2010, for a recent review). For example, Bushman and Piotroski (2006, p. 109) show that financial reporting practices are more conservative in jurisdictions with "high quality judicial regimes." Conclusions from this literature can be used to motivate hypotheses to test how the properties of corporate accountability reports vary in complementary institutions. Such evidence is likely to help evaluate the effectiveness of corporate accountability reports. For instance, in circumstances where employees have a valid ownership claim to resources under shareholder control, we can predict, ex ante, that corporate reporting on employee practices in a country such as Germany is likely to be more effective in aligning shareholders with employee interests than such reporting in a country such as China. This is because complementary institutions such as labor unions are more developed in Germany than in China. Analogously, corporate reporting on environmental practices is likely to be more effective in reducing companies' carbon footprints in the European 
Union versus the U.S., given stricter environmental enforcement in the former (e.g., Marquis and Toffel, 2011). Similar predictions can be made across other contextual factors and across other types of reporting, such as reporting on corruption.

Third, the delegation-based view of accountability creates a demand for reporting. A system of reporting, by encouraging performance measurement, can result in a delegate internalizing the consequences of her actions, very likely then affecting which actions she pursues. ${ }^{17}$ Whether such actions are welfare improving is, however, an empirical question, one that has been studied in the context of financial reporting (albeit, necessarily, in partial equilibrium settings). On the one hand, performance measurement allows delegators and delegates to make better trade-offs. For example, financial reporting necessitates measurement of a firm's financial performance, which in turn allows the firm's managers and owners to make, on average, better capital allocation decisions. ${ }^{18}$ On the other hand, a literature in accounting on managers' functional fixation on reported numbers suggests that in some cases reporting can result in value destroying activities (see Kothari, 2001, for a discussion of functional fixation studies in accounting). For example, Bartov, Givoly, and Hayn (2002) find evidence of firms opportunistically managing reported earnings to meet or beat expectations of those earnings set by financial analysts. As with the 'earnings management' literature in financial reporting, a parallel research agenda in accountability reporting is likely to emerge. Relatedly, the literature in multi-tasking suggests that when agents facing multiple tasks are evaluated (and rewarded) along only some dimensions, non-evaluated tasks suffer (Holmstrom and Milgrom, 1991; Baker, 1992; see Bushman and Smith,

\footnotetext{
${ }^{17}$ Put differently, measurement affects actions (e.g., Johnson and Kaplan, 1987, p. 2). Also see Tetlock’s work (e.g., 1985) on how an accountability system can alter cognition and action.

${ }^{18}$ See, for example, Healy and Palepu (2001), Hail, Leuz, and Wysocki (2010), and Kothari et al. (2010).
} 
2001, for a review of related work in accounting). By analogy, if corporate accountability reports emphasize internalizing certain dimensions of firm externalities over others, the reports can have the perverse effect of narrowing the span of managers' efforts: testing this proposition is another opportunity for future research. (I further address the issue of welfare consequences of accountability reporting in Section IV.)

A fourth research opportunity from the delegation-based model of accountability is that the reporting it generates necessitates measurement. Such measurement, in turn, requires a basis (units). In traditional financial reporting, prices of historic input costs serve as the basis for accountability. Over the past two decades, new standards have been introduced into public financial reporting that use estimated current-value prices as their basis. ${ }^{19}$ The choice between historic input costs and current-value estimates as the basis for financial reporting is one of the most active and contentious areas of debate in accounting research. ${ }^{20}$ This debate is contained within a relatively well-understood price system. By contrast, research on corporate accountability reporting is likely to confront several non-price bases for reporting, such as carbon units, water units, and solid-waste units. In corporate accountability reports, the price system may be an inadequate or inappropriate basis for measurement due to externalities. If the debate over measurement bases in accounting is an indicator, the issue of measurement bases for accountability more generally is likely to be an active area in future research and practice. The complexity of measurement in accountability reporting is related to one of the key

\footnotetext{
${ }^{19}$ Examples of accounting standards that use fair values include: impairment of long-lived assets (SFAS 121 in 1995 and SFAS 144 in 2001), employee stock options (SFAS 123 in 1995 and SFAS 123R in 2005), derivatives and hedging (SFAS 133 in 1998), acquired goodwill (SFAS 142 in 2001), and financial assets and liabilities (SFAS 159).

${ }^{20}$ See for example, Holthausen and Watts (2001), Barth et al. (2001), Ryan (2008), Laux and Leuz (2009), and Kothari et al. (2010).
} 
findings in the incentive-contracting literature in agency theory: that complex tasks are not rewarded through explicit contracts because of difficulties in objectively evaluating performance (e.g., Prendergast, 1999).

\section{What makes corporate accountability reports useful? Hypotheses from accounting theory}

Under the delegation-based view adopted in the prior section, a system of corporate accountability involves reporting by delegates to delegators. What are the properties of such reporting? Particularly, what properties are likely to make an observed system of corporate accountability useful to delegators in the context of the uncertainty and information asymmetry in which accountability takes place? In this section, I leverage positive accounting theory to identify three best-practice properties of corporate accounting: (1) mitigating information advantages across preparers and users; (2) reporting both stocks and flows in the unit of account; and (3) matching costs to benefits as those benefits are recognized. In three successive hypotheses, I argue that these practices are likely to improve the usefulness of corporate accountability reports.

\section{Mitigating information advantages}

In introducing a definition of accountability, I argue that 'delegation necessitates accountability.' The implication is that a framework for accountability requires a theory of delegation. The development of such a framework can thus begin by asking, "Why does one delegate?” The literature on agency relationships usually attributes delegation to one or both of two reasons: (1) the delegator has a better use for her time; (2) the delegate 
has better expertise to perform the delegated task (e.g., Berle and Means, 1932; Fama and Jensen, 1983). For example, shareholders delegate the management of a company to a chief executive (through a board of directors) because it is more cost-effective than directly managing the company and/or because the chief executive is more skilled at the task. Similarly, drawing from the example on BP in the introduction, one can argue that society delegates the extraction of oil to a corporation (via licensing) because the corporation is a more effective mechanism for the task and/or because the corporation is better skilled at the task. ${ }^{21}$ If neither of the conditions for delegation is true, then it is likely that the delegator will seek an alternative to the delegate; however, as discussed earlier, determining that the delegation conditions are not being met involves, in part, accountability reporting.

An important implication of the conditions for delegation outlined above is that the delegate is likely to have better information on her performance than the delegator. This is a relatively simple but critical insight to the framework for corporate accountability reporting: the preparer of accountability reports (delegate) is likely better informed of her performance than the user (delegator). A corollary, assuming rational self-interest, is that the delegate can exploit her information advantage to her own benefit. Addressing the information asymmetry between delegator and delegate is the focus of the first hypothesis on the properties of a corporate accountability reporting system.

\section{H1: Corporate accountability reporting that addresses a delegate's} information advantage in preparing reports is more useful to the delegator (than reporting that does not).

\footnotetext{
${ }^{21}$ As part of such a licensing agreement, the government of a society can specify an objective function (e.g., minimize extraction costs, minimize environmental impact, etc.).
} 
In the hypothesis above (and in subsequent hypotheses), "useful" refers to achieving the objectives of accountability; corporate accountability reporting is "useful" if it helps “explain” to the delegator the “delegate’s performance” (per Staubus' definition). In formulating the hypothesis, I do not specify empirical measures for usefulness because the measures are likely to vary with the delegator's objective function, which in turn is context specific. ${ }^{22}$ The vast accounting literature on evaluating the usefulness of financial reporting, including studies examining earnings quality, accounting's value-relevance, and its use in formal contracts, can be informative in developing metrics for "usefulness" in the context of corporate accountability reporting. ${ }^{23}$

How an accountability system addresses the information asymmetry between delegate and delegator is an important question for academic research. The specifics are likely to vary with the context in which that system is operating, including, as discussed earlier, with relevant complementary institutions. To see the context-specificity of an accountability system's response to the delegate's information advantage, consider, for example, the case of financial reporting. Over time, financial reporting has developed two principal mechanisms to account for delegates' information advantage: the first is that information in financial reports be verifiable (auditable); the second is that the information be conservative (i.e., a lower standard of verifiability is required for recognizing losses relative to gains). ${ }^{24}$ In addition to these two principal mechanisms,

\footnotetext{
${ }^{22}$ In practice, non-pecuniary units are often used in corporate accountability reports.

${ }^{23}$ For a recent review on earnings quality studies, see: Dechow, Ge, and Schrand (2010); for recent reviews on accounting's value-relevance, see Holthausen and Watts (2001) and Barth, Beaver, and Landsman (2001); for recent reviews on accounting's use in formal contracts, see Bushman and Smith (2001) and Armstrong et al. (2010).

${ }^{24}$ Although conservatism is still observed in accounting practice, accounting standard setters in the U.S. have attempted to eliminate conservatism from their conceptual framework for standard setting since at least the 1980s (FASB, 1980). It remains to be seen whether conservatism will continue to manifest in accounting practice over the coming years.
} 
there are other complementary institutions that help address delegates' information advantage in financial reporting, including, the timeliness and effectiveness of the law in enforcing abuses of that information advantage, and the existence and maturity of sophisticated intermediaries such as financial analysts (e.g., Healy and Palepu, 2001; Beyer et al., 2010). Research in accounting has shown that verifiability and conservatism of financial reporting vary across jurisdictions and across time in ways that are predictable from the development of legal and financial institutions (e.g., Basu, 1997; Ball, Kothari, Robin, 2000; Bushman and Piotroski, 2006).

There is considerable scope for the further development and refinement of H1 along the lines of exploring specific technologies that a corporate accountability system must adopt to address delegates’ information advantages. The survival of "verifiability" and "conservatism" in financial reporting suggests that such technologies are likely to transfer to corporate accountability reporting, but establishing whether this is the case is a question for future research. Two recent innovations in systems of corporate accountability can be useful in illustrating these points. The first involves B Lab, a nonprofit organization that claims to promote a new kind of legal entity: the B Corporation (as opposed to “C” or “S” Corporations). Registered B Corps (as of 2010, there were about 325 B Corps with combined revenues of about $\$ 1.5$ billion) must meet "rigorous standards of social and environmental performance” that are developed and certified by B Lab (Marquis, Klaber, Thomason, 2010). B Lab can be seen as bundling standard setting and assurance functions around corporate accountability, emphasizing "verifiability," but not necessarily “conservatism," in its standards. The second example, which also emphasizes "verifiability," is a worldwide industry association of 20 multinational 
mining companies and about 30 national and regional mining associations: the International Council on Mining and Metals (ICMM). Member companies of the ICMM, which include large players such as Alcoa and Anglo American, are required to make "a public commitment to improve their sustainability performance and are required to report against their progress on an annual basis” (International Council on Mining and Metals, 2011). The ICMM requires independent auditing of reports by its member companies, and even imposes a probationary period on new member companies as they progress towards basic compliance with ICMM standards.

In the context of the ICMM example, a specific prediction based on H1 might look as follows. Given a sample of mining firms that purport to produce accountability reports on their environmental impact, the reports of those firms that are admitted to the ICMM are, ceteris paribus, more likely to be used by national governments or transnational environmental watchdogs in evaluating the companies' environmental performance. In other words, when evaluating the environmental performance of nonICMM mining firms, environmental agencies are less dependent on firm-issued reports. This test design assumes the ICMM procedures provide some "verifiability" to the reporting process; thus the results must be interpreted as a joint test of H1 and the ICMM auditing mechanisms (similar to tests of "earnings quality" in the accounting literature that use auditing as a proxy for verifiability, e.g., Minnis, 2011). Note, this example is provided for illustrative purposes and is not exhaustive of feasible tests of H1.

Ex ante, the effectiveness of "verifiability" in mitigating information advantages is likely to vary based on the degree of information asymmetry in the agency relationship and on the degree of uncertainty linking delegates' actions to observable outcomes. For 
example, when reporting on corporate corruption-where fundamental uncertainty linking actions to outcomes is low-verifiability can be a more useful property of a corporate accountability system than when reporting on the environmental consequences of managers' activities - where a poor understanding of climate science can contribute to higher fundamental uncertainty.

\section{Reporting stocks and flows}

Under a delegation-based view, an accountability system focuses on aligning delegates to act in the interests of delegators. At the extremes, delegation can yield two undesirable outcomes for a delegator: (1) the delegate will shirk on the job; and (2) the delegate will gamble with the delegator's invested stock. That is, absent accountability, a shirking delegate may claim compensation for no effort; alternatively, an unaccountable delegate may take excessive risks with resources entrusted to her, expecting that she can negotiate for rewards if the risks yield positive outcomes, but suffer no consequences if the risks yield negative outcomes. These extreme characterizations of an unaccountable delegate are already familiar to students of agency theory who identify the problem in the context of monetized assets as the underinvestment and asset substitution problems (e.g., Myers, 1977; Smith and Warner, 1979).

To address these problems, I argue that an accountability system must serve the dual purposes of reporting on performance and position, or flows and stocks. Performance reporting-periodically assessing a delegate's efforts towards a stated objective — can address the problem of delegate shirking: a delegate is less likely to shirk if she is periodically made to report on her actions. Similarly, position reporting-taking 
periodic stock of the resources entrusted to a delegate-can address the problem of delegates gambling away those resources. These dual accountability functions of periodic performance and position reporting closely mirror what are often viewed as the primary functions of the income statement and balance sheet, respectively (e.g., Holthausen and Watts, 2001; Kothari et al., 2010). ${ }^{25}$ The demand for flow and stock reporting is the focus of the second hypothesis on the properties of a corporate accountability reporting system.

H2: Corporate accountability reporting that produces periodic measures of a delegate's performance and of the stock of resources under the delegate's management is more useful to the delegator (than reporting that does not).

Two issues arise from the hypothesis above. The first is related to performance reporting. Implicit in the idea of a performance report is an objective function: a delegate demands a performance report towards some objective. For example, in the context of the income statement, the shareholders' objective is maximizing financial returns. For the shareholder, the income statement is one indicator of the performance of a firm's management towards the objective of maximizing financial returns. The objective of a system of reporting on corporate accountability can variously be maximizing financial returns, minimizing environmental pollution, maximizing local employment, etc., depending on the delegator. Moreover, competing delegators with competing objectives can tug a single set of performance reports in different directions. Thus, in the case of income statements, bondholders-whose objective is likely stewardship of capital so that earns the rate of interest—-tug earnings toward conservatism (e.g., Watts, 2003).

\footnotetext{
${ }^{25}$ While the "income statement is primarily oriented toward performance measurement whereas the balance sheet primarily serves a stewardship role," these conclusions "do not imply that each statement exclusively serves one purpose or the other.” (Kothari et al., 2010, p. 260).
} 
Similarly, for example, in the case of a corporate accountability report on a firm's environmental activities, competing objectives from shareholders and a local community are likely to shape observed performance reporting practices (including the unit of measurement, e.g., monetary currency, carbon emissions, water use).

The second issue arising from $\mathrm{H} 2$ is related to position or stock reporting. The significance of stock reporting to accountability can be inferred by considering the counterfactual—by imagining a world where financial reporting consisted of only income statements. Balance sheets are essential to financial reporting because they give delegators (users of financial reports) a point-in-time estimate of the resources under the delegate's control and thus serve as a check against delegate expropriation. Financial reporting without balance sheets would do little to monitor for delegate "gambling." A similar argument can be made with regards to corporate accountability reporting.

In the context of $\mathrm{H} 2$, the absence of stock reporting in popular corporate accountability systems is germane. For example, consider the Connected Reporting Framework (CRF) launched in the UK by the prince of Wales' Accounting for Sustainability Project. CRF is promoted as a reporting model that "presents key sustainability information alongside more conventional financial information to give a more rounded and balanced picture of [an] organization's overall performance" (The Prince's Charities, 2009, p. 2.). Several prominent organizations including Aviva, Britain's largest insurer, BT, Britain's largest communications company, and HSBC, one of the world's largest banks, have adopted CRF as of 2011. The guidance in CRF is focused on five key indicators- "greenhouse gas emissions, energy usage, water use, waste, and significant use of other finite resources"-all of which are flow-based. Similar 
to the CRF indicators, the standards for environmental disclosure provided by the Global Reporting Initiative’s (GRI) Sustainability Reporting Guidelines (reproduced in Table 1) are flow-based (GRI guidelines are among the most high-profile accountability standards worldwide). The prediction from H2 is that CRF- and GRI-based reports are unlikely to be as useful to indented users as reports that would also include stock-based metrics.

Certain indicators on the GRI list may encourage firms to create stock-based reports. For example, consider EN18, “Initiatives to reduce greenhouse gas emissions and reductions achieved.” ${ }^{26}$ In reporting on these "initiatives,” some firms may create stockbased measures (e.g., periodic reporting on air quality around a firm's plant) in addition to the conventional flow reporting on greenhouse gas emissions usually observed (e.g., a plant's periodic greenhouse gas output). If so, a specific prediction from $\mathrm{H} 2$ might look as follows. Corporate accountability reports from firms with stock and flow measures of greenhouse gas emissions are more likely to be used by national governments or transnational environmental watchdogs in evaluating the firms' environmental stewardship (than corporate accountability reports from firms with only flow measures). The joint reporting of stock- and flow-based metrics allows delegators to better evaluate each metric individually and thus makes the reporting more useful. This test design holds constant issues with "verifiability" discussed in H1. Note, this example is provided for illustrative purposes and is not exhaustive of feasible tests of $\mathrm{H} 2$.

\footnotetext{
${ }^{26}$ Other indicators on the GRI list that may encourage firms to create stock-based reports include: EN6, "Initiatives to provide energy-efficient or renewable energy based products and services, and reductions in energy requirements as a result of these initiatives"; EN7, "Initiatives to reduce indirect energy consumption and reductions achieved"; EN14, "Strategies, current actions, and future plans for managing impacts on biodiversity"; and EN26, "Initiatives to mitigate environmental impacts of products and services, and extent of impact mitigation."
} 


\section{Matching}

$\mathrm{H} 2$ argues the advantage of corporate accountability reporting that produces periodic measures of a delegate's performance and of the stock of resources under the delegate's management. The periodic nature of reporting is necessitated by the differential horizons of delegates and the projects they manage. There is sometimes a lag between a delegate's actions and the outcome of those actions, and delegates may need to be evaluated in the interim. For example, when managers invest in a plant that is expected to create value within five years, they expect to be evaluated and compensated prior to the plant realizing its potential. The implication is that an accountability system must have a technology to match the cost of delegates' actions to the expected benefits from those actions. This demand for "matching" is an actively researched issue in accounting academe. ${ }^{27}$ The demand for matching is the focus of the third hypothesis on the properties of a corporate accountability reporting system.

H3: Corporate accountability reporting that has a technology to match across periods the actions of delegates and the outcomes of those actions is more useful to the delegator (than reporting that does not).

Developing effective matching remains one of the most difficult problems in financial reporting practice. There is unlikely to be a "silver bullet" that universally solves the matching problem in corporate accountability either. Explaining the variation

\footnotetext{
${ }^{27}$ Research on the "quality" of earnings (income) can be related to the elusive search for better matching in accounting since income is, after all, matched revenues and expenses (e.g., Dechow, 1994). The research and debates around fair-value accounting are also connected to the issue of matching (e.g., Kothari et al., 2010, p. 267). The growth of fair-value accounting in both U.S. GAAP and International Financial Reporting Standards (IFRS) is consistent with a diminished role for matching in financial reporting. However, for the most part, fair-value accounting is limited to financial assets and liabilities, except when dealing with impairment, where fair-value use is consistent with the matching principle. Moreover, since the financial crisis of 2008-09, the growth of fair values in U.S. GAAP and IFRS has slowed, in part due to political concerns about its role in that crisis. Some papers to specifically address matching include: Barclay, Gode, and Kothari (2005) and Dichev and Tang (2008).
} 
in matching technologies across observed accountability systems is likely to be an active area for future research. An effective matching technology is likely to be tied to assetspecific theories of value creation. ${ }^{28}$

Effective matching technologies in a corporate accountability system will likely possess two key properties: (1) a due process to address uncertainty and information asymmetry; and (2) a due process to address changes over time in uncertainty and information asymmetry. The "due process" gives legitimacy to the matching technology—it gives the delegator and delegate confidence in the accountability system's fairness (the analogy to such a due process in financial reporting is GAAP itself). Given the demand to report on a delegate's efforts before the outcome of such efforts is known (periodic performance reporting), the accountability system must provide a mutually agreeable technology (agreeable to delegate and delegator) that answers the question, What is the likelihood that a given action by the delegate will result in a particular outcome in a subsequent period? Further, conditional on reporting in a prior performance report the expectation of outcome from a delegate's effort, an accountability system must have mutually agreeable technology to address subsequent changes in that expectationhow to modify prior reported performance to reflect changes in the likelihood that a given action by the delegate will result in a particular outcome.

Matching technologies in financial reporting provide some examples of the two properties outlined above. For instance, in traditional, historic-cost accounting, the definition of an "asset" is the central technological element that addresses point (1): the asset definition provides a due process to address uncertainty and information asymmetry. In particular, the question before preparers and users of financial reports

\footnotetext{
${ }^{28}$ Thus, for example, the period over which capitalized plant is depreciated varies across firm-industries.
} 
(delegates and delegators) is what to do with a monetary expenditure (the "cost of effort") that a delegate argues will produce value in future periods. The solution is provided by the classical definition of an asset: the expenditure is "capitalized" (i.e., archived to count against future performance) if (a) a substantial portion of the effort required to produce the future value has already been exerted, (b) the effort is expected to generate "probable future economic benefits," and (c) such benefits are likely to be "controlled" by the delegator; otherwise the expenditure is "expensed" against current performance. The requirement (a) addresses the moral hazard problem that can arise given the delegate's information advantage (H1). The requirements (b) and (c) address uncertainty and information asymmetry: there is an extensive body of professional judgment and case law in accounting to interpret the phrases "probable future economic benefits" and "control."

Similarly, the traditional definition of asset "impairment" is the central technological element in historic-cost accounting that addresses the second property of a matching technology—that the technology includes a due process to address changes over time in uncertainty and information asymmetry. In particular, in financial reporting, if an expenditure is capitalized in the expectation that it will generate future economic benefits that are controllable, and if subsequent events reveal that those future economic benefits are less probable or less controllable, some or all of the capitalized amount is “impaired," i.e., expensed immediately against performance. Importantly, the converse is not true-in the traditional accounting model, if subsequent events reveal that future economic benefits are more probable or more controllable than previously thought, capitalized expenditure is not written up. This asymmetric treatment of good and bad 
news is an attempt of the matching technology in financial reporting to address delegates' information advantages and incentives (e.g., Watts, 2003).

Just as in the case of reporting stocks of the units of account (H2), there is noticeable absence of matching technologies among prominent standards for corporate accountability reporting such as the CRF and the GRI. This suggests that the technologies described in the hypotheses herein can be deployed toward improving in practice standards for corporate accountability reporting.

To see an example of a specific test based on the prediction from H3, consider the case of firms reporting both flow- and stock-based measures of their efforts to boost living standards in a community by sponsoring vocational education through community colleges (in line with "creating shared value" as outlined in Porter and Kramer, 2011). The flow-based measure can be periodic reporting on the number of vocational graduates sponsored by the firm and the stock-based measure can be a periodic measure of local living standards. The central prediction from $\mathrm{H} 3$ is that reporting that incorporates technologies to articulate the vocational-graduate flow metrics to the living-standard stock metrics is more likely to be useful to delegators (e.g., a local community) than reporting of stocks and flow metrics that do not articulate with each other. For these articulation technologies to be useful accountability tools, they must be agreed upon by delegates and delegators ex ante facto. The prediction above holds constant the verifiability issues raised in H1. Note, this example is provided for illustrative purposes and is not exhaustive of feasible tests of $\mathrm{H} 3$. 


\section{A skeptical appraisal of corporate accountability reporting}

As shown through the development of the three hypotheses above, an accountingbased research agenda in corporate accountability reporting can leverage insights from financial-reporting practice to inform the development of more effective measures of corporate accountability. Such "engineering" aside, there remains unanswered a more fundamental conceptual question as to whether corporate accountability reporting, in consuming scarce resources, creates or destroys value in society (a social-welfare analysis). A systematic research agenda in the area should eventually be able address questions on the economic efficiency of the observed phenomenon of corporate accountability reporting. In this section, I first offer three explanations for the phenomenon. The key distinction across the explanations is whether and how observed corporate accountability reporting creates or destroys value for the constituencies involved, with implications for social welfare. Next, I argue that the hypotheses developed in the previous section can be used to distinguish across these explanations in observed corporate accountability reports.

Three explanations for corporate accountability reporting

First, corporate accountability reporting can be, as described by Milton Friedman (1962, 1970), "window dressing” on part of shareholders or managers to earn reputational capital among one or more constituencies. In this case, corporate accountability reports only represent consumption, and do not effect resource-allocation decisions in ways that contribute to economic efficiency (thus, the 'reputation capital,' if earned, is unmerited). For example, some recent studies on firms' environmental disclosures have found such 
disclosures to be consistent with puffery or "greenwashing” (Lyon and Maxwell, 2011; Marquis and Toffel, 2011). The "window dressing" explanation does not imply that the reporting is costless: earning reputational capital with constituencies requires expending resources on providing an aura of legitimacy. ${ }^{29}$ Thus, if corporate accountability reporting is best explained as "window dressing," it is unlikely to create benefits beyond consumption and is likely to result in social-welfare losses.

Second, corporate accountability reporting can involve internalizing negative externalities (“externalities” as experienced by shareholders). Internalizing negative externalities can offset costs that are otherwise incurred by one or more firm constituencies (e.g., the cost to a local community from firm pollution), but may or may not improve social welfare. The social-welfare calculus will depend on the nature of the externality internalized - whether the cost to aggregate economic efficiency from its exclusion from the price system is greater than the cost of its internalization. Moreover, in some cases, the practice of internalizing negative externalities into firm decisions can benefit shareholders—viz., if the nature of costs avoided is such that they are eventually borne by shareholders if incurred (i.e., the externality comes back to bite). For example, due to ex-post settling up, BP shareholders eventually bore a substantial portion of the environmental costs from the Deepwater spill; thus corporate accountability reporting that focused management effort on oilrig safety could have saved shareholders money. In other cases, internalizing negative externalities into firm decisions can be valueextractive from a shareholder perspective because it diverts managers from shareholderreturn maximization and the cost savings accrue to non-shareholder constituents. For

\footnotetext{
${ }^{29}$ Beyond such "marketing” costs, corporate accountability reporting can be costly by distracting managers: Jensen (2002, p.237) argues, "Purposeful Behavior Requires the Existence of a Single-Valued Objective Function," so broader accountability systems (such as the Balanced Scorecard) are "flawed."
} 
example: corporate accountability reporting that curbs pollution in a local pond when there are no legal penalties to such pollution. ${ }^{30}$ Thus, in contrast to the "window dressing" explanation where no externalities are internalized and net welfare losses are likely, under this explanation for corporate accountability reporting, resource allocation decisions are affected and net welfare effects are ex ante indeterminate.

The third explanation for corporate accountability reporting also involves internalizing externalities, with variable net welfare effects; the difference is that the externalities are “positive.” That is, internalizing the externalities creates benefits for one or more firm constituencies. In some cases, shareholders may be able to privately capture at least some of these benefits, resulting in "shared value” (Porter and Kramer, 2011) between shareholders and other constituents. ${ }^{31}$ In this case, net welfare effects are likely positive. For example, managers incented to invest in regional community-colleges through corporate accountability metrics can find themselves with access to more productive employees, the benefits of the community colleges also accruing to the local population in general. In other cases, internalizing positive externalities may result in benefits that are difficult for shareholders to capture privately; and if such activities divert managers from shareholder-return maximization, the activities are value-destructive to shareholders. In this case, net welfare effects are ex ante indeterminate. ${ }^{32}$

\footnotetext{
${ }^{30}$ See, for example, Baron (2001, 2003) for a discussion of how "activist stakeholders" can employ political power to influence management decision-making in ways that harm shareholders. Porter and van der Linde (1995) argue that the dynamic nature of competition through innovation is such that even when firms are forced by "activists" to internalize certain negative environmental externalities, the firms (shareholders) can emerge ahead by developing lower-cost production functions.

${ }^{31}$ On the subject of reporting systems' potential to unleash synergies between firms, customers, and suppliers, see the discussion of the Balanced Scorecard in Kaplan and Norton (2006).

32 The distinction between the second and third explanations is a matter of framing with respect to the status quo (the state of the world where the firm does not internalize the externality). Internalizing negative externalities involves avoiding costs that are otherwise incurred by one or more firm constituencies; internalizing positive externalities involves generating benefits that are otherwise forgone by one or more
} 


\section{Telling the explanations apart}

The preceding subsection introduces three explanations for observed corporate accountability reporting: window dressing; internalizing negative externalities; and internalizing positive externalities. H1 through H3 propose three properties from accounting practice that can be used to evaluate observed accountability reporting: mitigating information advantages; reporting stocks and flows; and matching. Can the incidence of these practices be used to distinguish between the three explanations? In what follows, I provide some arguments to this effect (see also Figure B).

Consider the first explanation, window dressing. By definition, 'window dressing' represents costly consumption that does not affect real managerial decisions (i.e., does not internalize externalities). However, as discussed earlier, to be effective in its objective-earning (unmerited) reputational capital, the window dressing must seem credible (create an aura of legitimacy). Thus, we can expect corporate accountability reports that are generated for window dressing purposes to include some technologies aimed at mitigating information advantages (H1). Such technologies are unlikely to be sophisticated or substantive (such as the conservatism seen in financial reporting) since the reporting does not capture any underlying real actions. Additionally, such reports are unlikely to include technologies for reporting on stocks and flows (H2) or for matching (H3) since these are costly technologies unnecessary in the absence of real actions to internalize externalities. The first row in Figure B visualizes these predictions.

Turning to the second explanation, internalizing negative externalities, where corporate accountability reporting is expected to affect firm decisions in ways that offset

firm constituencies. Of course, viewed from frames other than the status quo, avoiding costs is an indirect benefit and forgoing benefits is an indirect cost, so the distinction between "negative" and "positive" externalities is relative. 
costs that are otherwise incurred by one or more firm constituencies. Here too, for the reporting to be credible to delegators, it will likely include some technologies aimed at mitigating delegates’ information advantages (H1). Additionally, such reports are likely to include technologies for reporting on both stocks and flows (H2). Since internalizing negative externalities involves real actions by delegates, reporting on stocks and flows will improve the quality of accountability. As argued in H2, performance and position statements serve complementary roles in an accountability system-the former addressing delegate "shirking," the latter delegate "gambling” of resources endowed by the constituency. For example, corporate accountability reporting demanded by a local community to curb water pollution in a local pond, if effective, is likely to include periodic measures of effluent releases into the pond (flows) as well as periodic indicators of the pond's overall water quality (stock). But corporate accountability reports generated for internalizing negative externalities are unlikely to include matching technologies (H3). As argued in H3, matching is necessitated when investments incurred in the current period are expected to generate direct benefits in future periods: by definition, internalizing negative externalities is a cost-avoidance explanation so matching to future direct benefits is infeasible. ${ }^{33}$ The second row in Figure B visualizes the predictions on internalizing negative externalities.

In the third explanation, internalizing positive externalities, corporate accountability reporting is expected to affect firm decisions in ways that create benefits

\footnotetext{
${ }^{33}$ Put differently, in the case of internalizing negative externalities, if the firm is to change its actions to avoid costs to one or more constituencies, reporting to this effect cannot involve matching because (by definition) there are no associated future benefits to match with. A similar situation exists in financial reporting, where costs are capitalized (and "matched" to future revenue) if there are reasonable and measurable future benefits; but if there are no future benefits associated with an action (e.g., settling a lawsuit), the costs are written off. Importantly, costs are not capitalized against future benefits unrelated to those costs.
} 
for one or more firm constituencies. An accountability system that is useful to delegators under these circumstances will likely include some technology to match current period investments to expected future benefits (H3). For example, corporate accountability reporting demanded by a local community toward improving local living standards, if effective, is likely to include some technology to match investments to this effect (e.g., investments in local community colleges) to purported future benefits. In addition, for the reasons discussed in the paragraphs above, such a system will also likely include technologies aimed at mitigating delegates' information advantages (H1) and technologies for reporting on both stocks and flows (H2). The third row in Figure B visualizes these predictions.

Thus, as seen in Figure B, the three explanations for observed corporate accountability reporting - window dressing, internalizing negative externalities, and internalizing positive externalities—can be distinguished through the successive incidence of the corporate accountability reporting properties introduced in $\mathrm{H} 1-\mathrm{H} 3$. Conceptually, the three explanations are mutually exclusive—for example, if reports are used for internalizing externalities, then, by definition, they are not "window dressing." But, as a practical matter, because reports address numerous constituencies and numerous actions, it is conceivable that all three explanations concurrently play some part in generating observed corporate accountability reporting. In this case, tests of the nature described in Figure B can be used to identify the prevailing explanation among the three.

An example of the tests envisioned in this section is as follows. Consider the case of firms reporting data on their greenhouse gas emissions. The professed objective here is internalizing negative externalities, i.e., reducing harm to the environment; although the 
reporting can be simply "window dressing.” As discussed above, if these reports include some auditing or verifiability technologies in line with the arguments in H1, they are consistent with both window dressing and internalizing negative externalities. But, if they additionally include stock metrics related to greenhouse gas emissions in line with the arguments in $\mathrm{H} 2$ (e.g., periodic air-quality metrics linked to their emissions activity), they are less likely to be engaged in window dressing and more likely to be effecting real actions that internalize negative externalities. Thus, the explanations can be told apart through joint examinations of the incidences of reporting technologies.

As another example, reconsider the previously introduced case of firms reporting on their efforts to create "shared value" in their local community by sponsoring vocational education through community colleges. Here, the professed objective is internalizing positive externalities, although the reporting can be window dressing. To tell these explanations apart, we can examine the properties of firm reports. If the reports are verifiable (H1), include flow- and stock-based measures (H2), and mutually agreeable matching technologies to articulate how flow measures (e.g., number of vocational graduates sponsored by the firm) connect to stock measures (e.g., local living standards), then it is unlikely that the firm is simply engaging in window dressing. Rather, it is more likely the firm is effecting real actions that seek to internalize positive externalities.

\section{Conclusion and implications for practice}

In this paper, I outline a framework for accounting-based research on corporate accountability reporting. Such research is timely given the increasing incidence of corporate accountability reporting in the economy. In Section II, I provide a definition for 
corporate accountability that draws on the delegation or "agency" view of accounting. I argue: (1) that delegation necessitates accountability; and (2) that accountability involves reporting. In other words, corporate accountability reporting is seen as arising from a delegator's (e.g., a citizenry) demand to hold a delegate (e.g., shareholders) to account. When effective, corporate accountability reporting is an informational channel that can internalize certain externalities into firms' resource allocation decisions, although doing so will not always serve shareholders' interests. In Section III, I introduce three hypotheses that I argue are likely to identify systems of corporate accountability reporting more useful to delegators. These hypotheses are motivated from theory and evidence in the positive accounting literature. I propose that an accountability reporting system is likely to be more useful to a delegator if it: (1) mitigates information advantages across delegates and delegators; (2) reports both stocks and flows in the measures of account; and (3) has a mutually agreeable due process to match across periods the actions of delegates and the outcomes of those actions. The hypotheses offer opportunity for numerous cross-sectional and time-series studies of observed corporate accountability reports. Tests of these hypotheses can be a starting point towards a theory of corporate accountability reporting.

The technologies specified in these hypotheses are common in financial reporting practice, but casual empiricism suggests they are not prevalent in accountability reporting. For instance, consider the B-Lab standards, the ICMM standards, the prince of Wales' CRF, and the GRI guidelines all discussed in the paper. The B-Lab and ICMM are organizations that are promoting verifiability in corporate accountability reporting. But such verifiability alone is insufficient to establish that B-Lab and ICMM standards 
are useful to the constituents they serve. If B Lab and the ICMM are to survive in the long run, we can expect them to develop stock-and-flow reporting and, perhaps, matching technologies within their reporting frameworks. Similarly, the absence of stock reporting technologies and matching technologies in the CRF and GRI standards (which are widely prevalent in corporate accountability reports) suggests that these standards are primitive relative to financial reporting equivalents. Moreover, neither the CRF nor the GRI standards have clearly tackled verifiability or auditability, suggesting that both standards must evolve rapidly if they are to survive. Thus, the reporting technologies embedded in the paper's three hypotheses can be deployed toward improving in practice standards for corporate accountability reporting.

In Section IV, I offer a skeptical appraisal of corporate accountability reporting aimed at exploring when and how observed corporate accountability reports create or destroy value for shareholders and other constituencies. I offer three explanations for observed corporate accountability reports: (1) Milton Friedman’s “window dressing” explanation, where such reports are superficial and do not internalize externalities into firm decisions; (2) such reports are an attempt at internalizing negative externalities, as identified by one or more firm constituencies, into firm decisions; and (3) such reports are an attempt at internalizing positive externalities, as identified by one or more firm constituencies, into firm decisions. I show how the hypotheses developed in Section III can be used to distinguish across these explanations in observed corporate accountability reports. A research agenda along these lines can help improve reporting practice and eventually address the fundamental question in this area — what are the net welfare effects of corporate accountability reporting. 


\section{References:}

Armstrong, C., W. Guay, and J. Weber. 2010. "The role of information and financial reporting in corporate governance and debt contracting," Journal of Accounting \& Economics 50, nos. 2-3.

Arrow, K. 1985. “The economics of agency,” in J. Pratt, and R. Zeckhauser (Eds.), Principals and Agents: The Structure of Business. Boston, Mass: Harvard Business School Press.

Baker, G. 1992. “Incentive contracts and performance measurement,” Journal of Political Economy 100, no. 3.

Ball, R. 2001. "Infrastructure requirements for an economically efficient system of public financial reporting and disclosure,” in R. Litan, and R. Herring (Eds.), BrookingsWharton Papers on Financial Services. Washington, D.C.: Brookings Institution Press.

Ball, R., S. Kothari, and A. Robin. 2000. "The effect of international institutional factors on properties of accounting earnings,” Journal of Accounting \& Economics 29, no. 1.

Barclay, M., D. Gode, and S. Kothari. 2005. “Matching Delivered Performance,” Journal of Contemporary Accounting \& Economics 1, no. 1.

Baron, D. 2001. "Private Politics, Corporate Social Responsibility, and Integrated Strategy” Journal of Economics \& Management Strategy 10, no. 1.

Baron, D. 2003. “Private Politics,” Journal of Economics \& Management Strategy 12, no. 1.

Barth, M., W. Beaver, and W. Landsman. 2001. "The relevance of the value-relevance literature for financial accounting standard setting: another view," Journal of Accounting \& Economics 31, nos. 1-3.

Bartov, E., D. Givoly, and C. Hayn. 2002. "The rewards to meeting or beating expectations,” Journal of Accounting \& Economics 33, no. 2.

Basu, S. 1997. "The conservatism principle and the asymmetric timeliness of earnings," Journal of Accounting \& Economics 24, no 1.

Bates, D. 2010. "BP accepts blame for Gulf of Mexico spill after leaked memo reveals engineer misread pressure reading," The Daily Mail, August 30, http://www.dailymail.co.uk/news/worldnews/article-1307439/.

Bator, F. 1958. “The Anatomy of Market Failure,” Quarterly Journal of Economics 72, no. 3.

BBC News. 2010. “Gulf oil spill: President's panel says firms complacent,” November 9, http://www.bbc.co.uk/news/world-us-canada-11720907. 
Berle, A. and G. Means. 1932. The Modern Corporation and Private Property. New York: Harcourt, Brace \& Company.

Beyer, A., D. Cohen, T. Lys, and B. Walther. 2010. "The financial reporting environment: review of the recent literature," Journal of Accounting \& Economics 50, nos. 2-3.

Bowen, R., L. DuCharme, and D. Shores. 1995. "Stakeholders' implicit claims and accounting method choice,” Journal of Accounting \& Economics 20, no. 3.

Bushman, R., and J. Piotroski. 2006. "Financial reporting incentives for conservative accounting: The influence of legal and political institutions," Journal of Accounting \& Economics 42, nos. 1-2.

Bushman, R., and A. Smith. 2001. "Financial accounting information and corporate governance,” Journal of Accounting \& Economics 32, nos. 1-3.

Crane, A., A. McWilliams, D. Matten, J. Moon, and D. Siegel. 2008. The Oxford handbook of corporate social responsibility. Oxford: Oxford University Press.

Cooter, R. and B. Freedman. 1991. "The fiduciary relationship: its economic character and legal consequences," New York University Law Review 42, no. 4.

Dechow, P. 1994. "Accounting earnings and cash flows as measures of firm performance: The role of accounting accruals," Journal of Accounting \& Economics 18, no. 1.

Dechow, P., W. Ge, and C. Schrand. 2010. "Understanding earnings quality: A review of the proxies, their determinants, and their consequences," Journal of Accounting \& Economics 50, nos. 2-3.

Dichev, I. and V. Tang. 2008. "Matching and the Changing Properties of Accounting Earnings over the Last 40 Years," Accounting Review 83, no. 6.

Eccles, R., G. Serafeim, and P. Andrews. 2011. "Mandatory Environmental, Social, and Governance Disclosure in the European Union,” Harvard Business School Case 111-120.

Fama, E. and M. Jensen. 1983. "Separation of Ownership and Control," Journal of Law and Economics 26, no. 2.

Financial Accounting Standards Board. 1980. "Qualitative Characteristics of Accounting Information” Statement of Financial Accounting Concepts no. 2. Norwalk, CT: Financial Accounting Standards Board (FASB).

Friedman, M. 1962. Capitalism and Freedom. Chicago: University of Chicago Press.

Friedman, M. 1970. "The Social Responsibility of Business is to Increase its Profits," New York Times Magazine, September 13. 
Gibbons, R. 2010. "Inside Organizations: Pricing, Politics, and Path Dependence," Annual Review of Economics 2.

Global Reporting Initiative. 2001-2011. Sustainability Reporting Guidelines. Amsterdam: Global Reporting Initiative (GRI).

Hail, L., C. Leuz, and P. Wysocki. 2010. "Global Accounting Convergence and the Potential Adoption of IFRS by the U.S.,” Accounting Horizons 24, no. 3.

Hart, O. 1995. Firms, Contracts, and Financial Structure. Oxford: Oxford University Press.

Hayes, R. and S. Schaefer. 2000. "Implicit Contracts and the Explanatory Power of Top Executive Compensation for Future Performance," RAND Journal of Economics 31, no. 2.

Healy, P. and K. Palepu. 2001. "Information asymmetry, corporate disclosure, and the capital markets: a review of the empirical disclosure literature," Journal of Accounting \& Economics 31, nos. 1-3.

Hill, C. and T. Jones. 1992. "Stakeholder-Agency Theory," Journal of Management Studies 29, no. 2.

Holmstrom, B. and P. Milgrom. 1991. "Multitask Principal-Agent Analyses: Incentive Contracts, Asset Ownership, and Job Design," Journal of Law, Economics \& Organization 7, sp.

Holthausen, R. and R. Watts. 2001. "The relevance of the value-relevance literature for financial accounting standard setting," Journal of Accounting \& Economics 31, nos. 1-3.

Hopwood, A. 2009. “Accounting and the environment," Accounting, Organizations and Society 34, nos. 3-4.

Hsieh, N. 2009. "Does Global Business Have a Responsibility to Promote Just Institutions?” Business Ethics Quarterly 19, no. 2.

International Council on Mining and Metals. 2011. “ICMM—About Us.” Accessed, July 28, 2011. http://www.icmm.com/about-us.

Jensen, M. 2002. "Value Maximization, Stakeholder Theory, and the Corporate Objective Function,” Business Ethics Quarterly 12, no. 2.

Jensen, M. and W. Meckling. 1976. "Theory of the firm: managerial behavior, agency costs, and ownership structure," Journal of Financial Economics 3, no. 4.

Johnson, H. and R. Kaplan. 1987. Relevance Lost. Boston, Mass: Harvard Business Press.

Kaplan, R. and D. Norton. 2006. Alignment: Using the Balanced Scorecard to Create Corporate Synergies. Boston, Mass: Harvard Business Press. 
Khanna, T. and K. Palepu. 2010. Winning in Emerging Markets: A Roadmap for Strategy and Execution. Boston, Mass: Harvard Business Press.

Kitzmueller, M. and J. Shimshack. 2012. "Economic Perspectives on Corporate Social Responsibility,” Journal of Economic Literature 50, no. 1.

Kothari, S. 2001. "Capital markets research in accounting," Journal of Accounting \& Economics 31, nos. 1-3.

Kothari, S., K. Ramanna, and D. Skinner. 2010. "Implications for GAAP from an analysis of positive research in accounting," Journal of Accounting \& Economics 50, nos. 2-3.

La Porta, R., F. Lopez-de-Silanes, A. Shleifer, and R. Vishny. 2000. “Investor protection and corporate governance,” Journal of Financial Economics 58, no. 1.

Lambert, R. 2001. "Contracting theory and accounting," Journal of Accounting \& Economics 32, nos. 1-3.

Laux, C. and C. Leuz. 2009. "The crisis of fair-value accounting: Making sense of the recent debate,” Accounting, Organizations and Society 34, nos. 6-7.

Lerner, J. and P. Tetlock. 1999. “Accounting for the effects of accountability," Psychological Bulletin 125, no. 2.

Lyon, T. and J. Maxwell. 2011. "Greenwash: Corporate Environmental Disclosure under Threat of Audit,” Journal of Economics \& Management Strategy 20, no. 1.

Margolis, J. and J. Walsh. 2001. People and Profits: The Search for a Link between a Company's Social and Financial Performance. Rahway, NJ: Erlbaum Associates.

Margolis, J. and J. Walsh. 2003. "Misery Loves Companies: Rethinking Social Initiatives by Business,” Administrative Science Quarterly 48, no. 2.

Marquis, C., A. Klaber, and R. Thomason. 2010. "B Lab: Building a New Sector of the Economy,” Harvard Business School Case 411-047.

Marquis, C. and M. Toffel. 2011. “The Globalization of Corporate Environmental Disclosure: Accountability or Greenwashing?” Harvard Business School Working Paper 11-115.

Melé, D. 2008. “Corporate social responsibility theories,” in A. Crane, A. McWilliams, D. Matten, J. Moon, and D. Siegel (Eds.), The Oxford handbook of corporate social responsibility. Oxford: Oxford University Press.

Minnis, M. 2011. “The Value of Financial Statement Verification in Debt Financing: Evidence from Private U.S. Firms,” Journal of Accounting Research 49, no. 2.

Mitchell, R., B. Agle, and D. Wood. 1997. “Toward a Theory of Stakeholder Identification and Salience: Defining the Principle of Who and What Really Counts," The Academy of Management Review 22, no. 4. 
Myers, S. 1977. "Determinants of corporate borrowing," Journal of Financial Economics 5, no. 2.

Ostrom, E. 2011. "Reflections on 'Some Unsettled Problems of Irrigation,” American Economic Review 101, no. 1.

Owen, D. and B. O’Dwyer. 2008. “Corporate social responsibility: The reporting and assurance dimension,” in A. Crane, A. McWilliams, D. Matten, J. Moon, and D. Siegel (Eds.), The Oxford handbook of corporate social responsibility. Oxford: Oxford University Press.

Porter, M. and M. Kramer. 2011. “Creating Shared Value,” Harvard Business Review 89, nos. 1-2.

Porter, M. and C. van der Linde. 1995. "Toward a new conception of the environmentcompetitiveness relationship,” Journal of Economic Perspectives 9, no. 4.

Prendergast, C. 1999. “The provision of incentives in firms," Journal of Economic Literature 37, no. 1.

The Prince’s Charities. 2009. “Connected Reporting in Practice: A Consolidated Case Study,” London: The Prince’s Charities.

Reinhardt, F., R. Stavins, and R. Vietor. 2008. "Corporate Social Responsibility Through an Economic Lens,” Review of Environmental Economics and Policy 2, no. 2.

Ross, S. 1973. “The economic theory of agency: the principal's problem,” American Economic Review 63, no. 2.

Ryan, S. 2008. “Accounting in and for the Subprime Crisis,” Accounting Review 83, no. 6.

Scherer, A. and G. Palazzo. 2008. “Globalization and corporate social responsibility,” in A. Crane, A. McWilliams, D. Matten, J. Moon, and D. Siegel (Eds.), The Oxford handbook of corporate social responsibility. Oxford: Oxford University Press.

Scott, B. 2009. The Concept of Capitalism. New York: Springer.

Smith, C. and J. Warner. 1979. "On financial contracting: An analysis of bond covenants,” Journal of Financial Economics 7, no. 2.

Staubus, G. 2003. “Accounting, accountability, auditing, and financial scandals over the centuries,” Working paper, SSRN abstract \#1733229.

Stavins, R. 2011. "The Problem of the Commons: Still Unsettled after 100 Years," American Economic Review 101, no. 1.

Tetlock, P. 1983. “Accountability and complexity of thought,” Journal of Personality and Social Psychology 45, no. 1. 
Tetlock, P. 1985. "Accountability: A social check on the fundamental attribution error," Social Psychology Quarterly 48, no. 3.

Tirole, J. 1999. “Incomplete contracts: where do we stand?” Econometrica 67, no. 4.

Watts, R. 2003. "Conservatism in accounting, Part I: explanations and implications," Accounting Horizons 17.

Watts, R., and J. Zimmerman. 1986. Positive Accounting Theory. Englewood Cliffs, NJ: Prentice Hall.

Weber, M. 1947. The theory of social and economic organization. New York: Free Press.

Williamson, O. 1985. The Economic Institutions of Capitalism. New York: Free Press. 


\section{Table 1: GRI's Environmental Performance Indicators}

\begin{abstract}
EN1 Materials used by weight or volume.
EN2 Percentage of materials used that are recycled input materials.

EN3 Direct energy consumption by primary energy source.

EN4 Indirect energy consumption by primary source.

EN5 Energy saved due to conservation and efficiency improvements.

EN6 Initiatives to provide energy-efficient or renewable energy based products and services, and reductions in energy requirements as a result of these initiatives.
\end{abstract}

EN7 Initiatives to reduce indirect energy consumption and reductions achieved.

EN8 Total water withdrawal by source.

EN9 Water sources significantly affected by withdrawal of water.

EN10 Percentage and total volume of water recycled and reused.

EN11 Location and size of land owned, leased, managed in, or adjacent to, protected areas and areas of high biodiversity value outside protected areas.

EN12 Description of significant impacts of activities, products, and services on biodiversity in protected areas and areas of high biodiversity value outside protected areas.

EN13 Habitats protected or restored.

EN14 Strategies, current actions, and future plans for managing impacts on biodiversity.

EN15 Number of IUCN Red List species and national conservation list species with habitats in areas affected by operations, by level of extinction risk.

EN16 Total direct and indirect greenhouse gas emissions by weight.
EN17 Other relevant indirect greenhouse gas

emissions by weight.

EN18 Initiatives to reduce greenhouse gas emissions and reductions achieved.

EN19 Emissions of ozone-depleting substances by weight.

EN20 NO, SO, and other significant air emissions by type and weight.

EN21 Total water discharge by quality and destination.

EN22 Total weight of waste by type and disposal method.

EN23 Total number and volume of significant spills.

EN24 Weight of transported, imported, exported, or treated waste deemed hazardous under the terms of the Basel Convention Annex I, II, III, and VIII, and percentage of transported waste shipped internationally.

EN25 Identity, size, protected status, and biodiversity value of water bodies and related habitats significantly affected by the reporting organization's discharges of water and runoff.

EN26 Initiatives to mitigate environmental impacts of products and services, and extent of impact mitigation.

EN27 Percentage of products sold and their packaging materials that are reclaimed by category.

EN28 Monetary value of significant fines and total number of non-monetary sanctions for noncompliance with environmental laws and regulations.

EN29 Significant environmental impacts of transporting products and other goods and materials used for the organization's operations, and transporting members of the workforce.

EN30 Total environmental protection expenditures and investments by type.

Source: Sustainability Reporting Guidelines, GRI 
Figure A

Corporate accountability reporting to a firm's constituency varies with the constituency's ownership claims and monitoring powers vis-à-vis the firm's shareholders

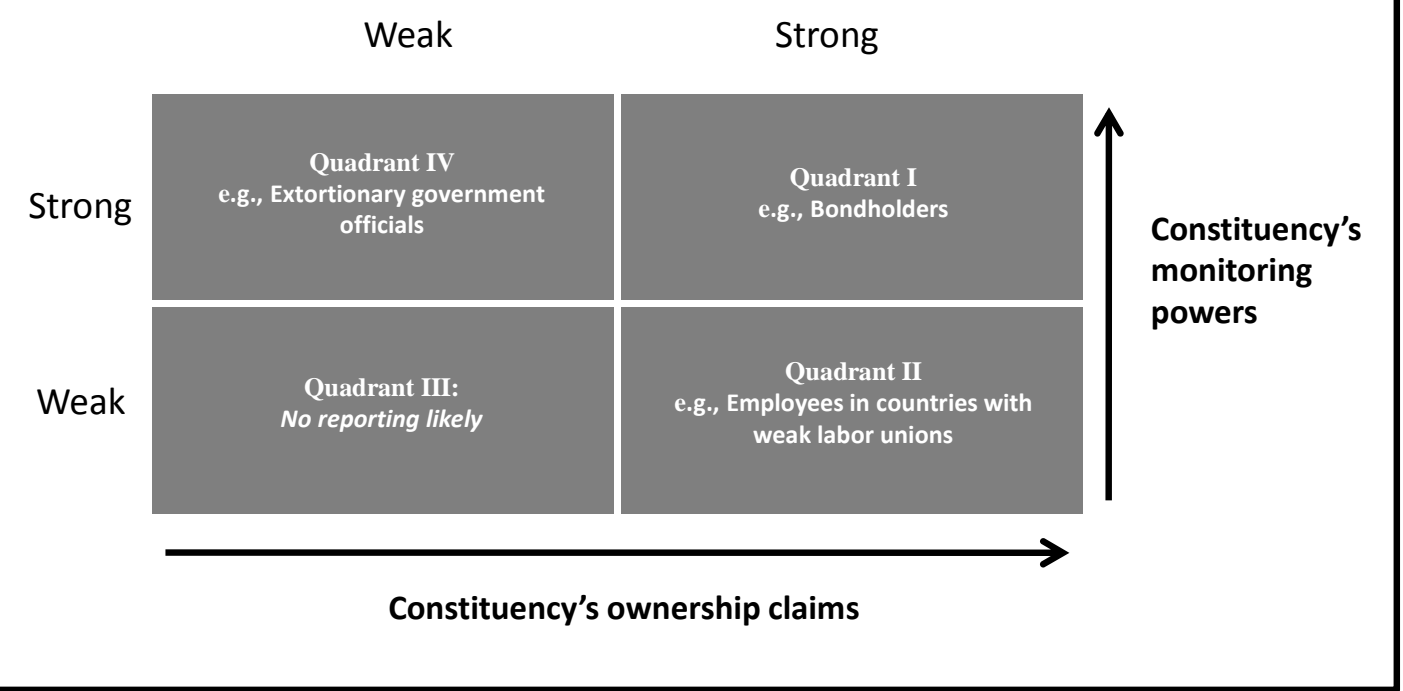


Figure B

Leveraging accounting theory to distinguish between the explanations for corporate accountability reporting

Properties of accounting inferred from theory

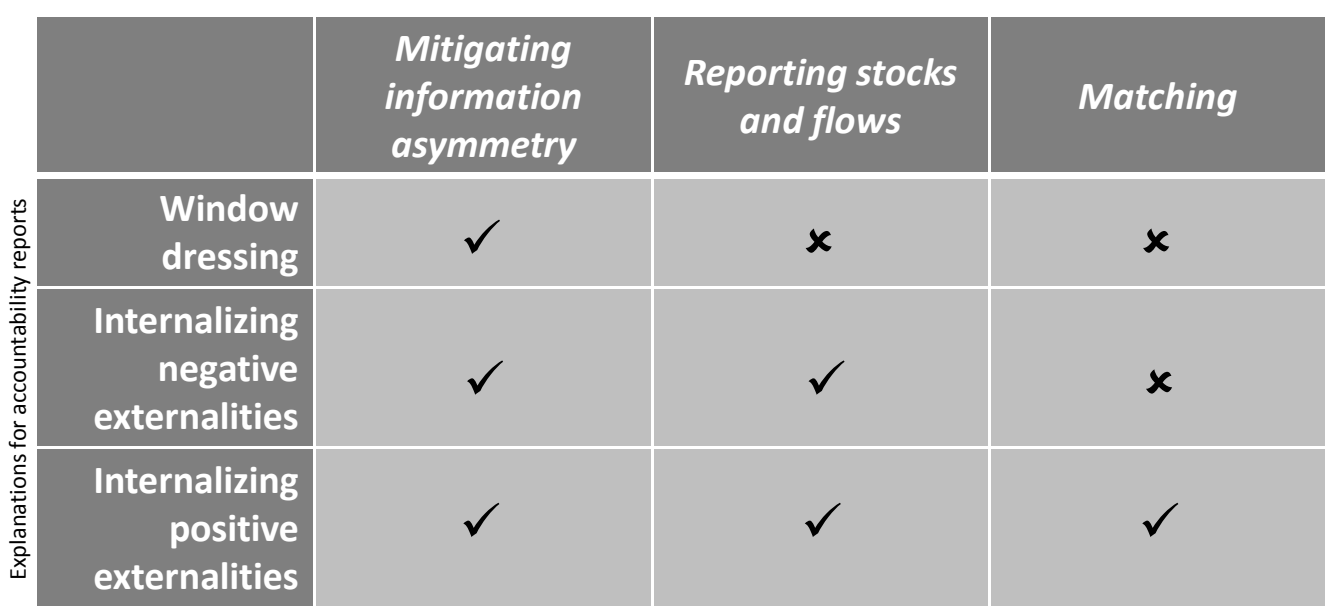

